Warszawskie Studia Pastoralne UKSW

Rok XII 2017 Nr 1(34)

ZOFIA KęPIŃSKa-WALCZAK

\title{
GENETIC DIAGNOSIS OF INTELLECTUAL DISABILITY AND ITS ETHICAL ASPECT
}

\section{Introduction}

Parents of a child with an intellectual disability experience a whole range of difficult emotions. At the same time, they want to know the cause of their child's disability and gain the most reliable knowledge on this topic. The term "intellectual disability" is used to refer to a lot of different types of disability, which may have different causes and degrees of severity. Intellectual disability is the most widespread and most commonly diagnosed disorder as indicated by numerous statistics ${ }^{1}$. How its occurrence rate is determined depends on the understanding of the term "intellectual disability". In 1975 in the United States it was calculated that mental disability affects $3.6 \%$ of children of school age ${ }^{2}$. In the Netherlands, it was estimated that approximately $3 \%$ of children have some kind of intellectual disability, while in France and Japan $-4.5 \%{ }^{3}$. Currently, the accepted rate for Europe ranges from $2.2 \%$ to $3.2 \%$. Intellectual disability affects $60-70 \%$ of all disabled children. This article will discuss genetic diagnostic methods for an intellectual disability in children as well as their ethical aspect. First, it will be explained what diagnosis generally is.

1 Cf. J. J. Błeszyński, Niepełnosprawność intelektualna. Mowa - język - komunikacja. Czy iloraz inteligencji wyjaśnia wszystko?, Gdańsk 2013, p. 11.

2 Cf. Upośledzenie umysłowe - pedagogika, ed. K. Kirejczyk, Warszawa 1981.

3 Cf. J. Wyczesany, Pedagogika upośledzonych umysłowo. Wybrane zagadnienia, Kraków 1999, p. 40. 
Next, the paper will attempt to characterize genetic diagnosis, and further - a reflection will be made on the ethical aspect of the genetic diagnosis of intellectual disability.

\section{The diagnosis of intellectual disability}

Today, in the era of medical and technical progress, the diagnosis of intellectual disability is possible at different stages of a child's life. There are various diagnostic methods, each of which uses different criteria and techniques to assess mental disability. The word "diagnosis" comes from the Greek word "diagnosis" and means "distinguishing; judging". The Greek word "diagnostike" is the art of distinguishing through indirect (mental) knowledge. Ziemski gives the following definition of "diagnosis": "identification of the nature and conditions of a complex state of affairs on the basis of its features (symptoms), using the knowledge of general characteristics of a given field of investigation"4. According to Mazurkiewicz, diagnosis is the "collection, interpretation and evaluation of data in a particular way, and then the determination of the investigated complex state of affairs, which is what differentiates diagnosis from the simple gathering of information and its organization"'. Podgórecki, on the other hand, states that diagnosis is the "formulation of hypothesis which gives grounds for the change of actual states, determined on the basis of a comprehensive description and evaluation of the examined empirical situations" 6 .

We can talk about a complete and partial diagnosis. A complete diagnosis is a "diagnosis made on the basis of the observed symptoms and well-known general characteristics of the examined complex state of affairs by assigning it to a given type or species, or through genetic and teleological explanation, determination of the current phase as

${ }^{4}$ Ibid.

5 Ibid.

6 Ibid., p. 41. 
well as prediction of future development"7. Ziemski has identified the following types of diagnosis:

- classification - assignment of data to a specific type or class;

- genetic diagnosis - focused on the origins and causes of the current state;

- prognostic diagnosis - looking for future states, which can be derived from the current state;

- functional diagnosis - finding the meaning of elements and defining the functions they perform in the analyzed whole;

- developmental diagnosis - the purpose may be developmental deficits (negative diagnosis) as well as areas of development in which an individual is advanced (positive diagnosis).

We can also talk about educational, environmental or social diagnosis. Diagnostics makes use of different sources of information, diagnostic procedures, and tools in order to collect data, formulate answers to the questions of interest and solve problems.

Currently, a genetic diagnosis can confirm genetic diseases, which are often coupled with intellectual disability. "The involvement of modern medicine and contemporary families in the creation of genetic awareness is the need of our times; however, we must remember that the human being is not only a collection of genes and a bearer of genetic patrimony" 8 . The genetic diagnosis not only allows us to assess the risk of illness or disability of the examined child, but also has an impact on the whole family, as it may indicate similar genetic carriership or the risk of the appearance of the same disease or disability in the family members, or the next child to be born.

\section{The characteristics of genetic diagnosis}

Genetic diagnosis uses genetic tests. P. S. Harper defines "genetic test" as "the analysis of a gene in its construction or functioning, as well as the study of DNA fragments or chromosomes in order to confirm or

7 Ibid.

8 W. Surmiak, Eugenika a testy genetyczne, "Osoby niepełnosprawne a życie rodzinne” 2011, No. 1/4, p. 29. 
rule out mutations usually associated with a certain disease" ${ }^{\text {". Based }}$ on this definition, we can distinguish two types of genetic testing ${ }^{10}$ :

- medical tests - they identify genetic abnormalities causing a disease that is already present in the human body, or indicate certain susceptibility to develop a given disease or a complex (multi-factor) disorder. The purpose of these tests is primarily to confirm the diagnosis of the already existing disease or indicate the risk of developing a disease in the future;

- non-medical tests - their primary objective is the analysis of markers indicating the presence of certain common or differentiating characteristics of particular individuals. These tests do not directly treat health-related issues, but are used primarily to determine paternity as well as in criminology.

In the diagnosis of children's intellectual disability it is medical tests that are crucial. We can distinguish the following types of medical tests based on the moment of their execution:

- diagnostic (symptomatic) tests

- pre-symptomatic (pre-clinical) tests

- predictive (likelihood) tests

- tests verifying heterozygosity

Genetic diagnosis can be performed at different stages of the child's life. Thus, genetic tests can be divided into:

- prenatal genetic tests

- postnatal genetic tests

Prenatal genetic testing includes a whole range of diagnostic tests which are executed before the baby is born. They are designed to assess the health status of the embryo or fetus and detect potential pathologies. Along with these tests, the so-called screening tests are also carried out. Their aim is to find other forms of pathologies that

9 P.S. Harper, What do we mean by genetic testing?, "Journal of Medical Genetics" 1997, No. 34, p. 749.

10 Cf. W. Surmiak, Eugenika a testy genetyczne, "Osoby niepełnosprawne a życie rodzinne" 2011, No. 1/4, p. 30. 
are possible to detect at various stages of pregnancy. Both genetic and screening tests have their optimal time of execution.

Prenatal tests can be divided into preimplantation and post-implantation tests. The former are carried out before the implantation of the embryo in the uterus. Here arises the issue of in vitro fertilization, as preimplantation genetic diagnosis is possible only in the case of artificial insemination. According to the classical approach to prenatal diagnosis, post-implantation prenatal testing serves to assess pathology or the risk of its emergence from the moment of the implantation of the embryo in the uterus until the birth of the baby. However, it should be stressed that, according to the Dignitas personae instruction, "preimplantation diagnosis is also a form of prenatal diagnosis"11.

Among post-implantation prenatal diagnosis methods we can distinguish non-invasive tests, which include, for example, ultrasound or screening tests, as well as invasive methods, e.g. fetal tissue biopsy or umbilical cord blood tests.

\section{Ethical aspect of genetic diagnosis}

The first bioethical problem of genetic diagnosis emerges in the context of invasive prenatal diagnostic tests which may pose a threat to the unborn child. Diagnostic tests must minimize the risk for the baby, who should be protected regardless of the suspected pathology in their development. Therefore, genetic diagnosis should always start with non-invasive methods. "It is worth mentioning that here applies the principle of proportionality of risk and its maximum reduction. The reduction of risk lies, above all, in the hands of the doctor conducting the test and is his deontological, ethical and legal obligation. (...) The proportion between the risk and expected benefits does not hold, though, in the case of a prior decision of possible pregnancy termination"12.

\footnotetext{
11 Kongregacja Nauki Wiary, Dignitas personae. Instrukcja dotycząca niektórych problemów bioetycznych, Watykan 2008, No. 22.

12 W. Surmiak, Eugenika a testy genetyczne, op. cit., pp. 37-38.
} 
Another aspect which should be taken into account in the context of ethics is the effectiveness of testing methods, both invasive and non-invasive ones. Tests do not necessarily give absolute certainty about the state of the child's health. The duty of a doctor is to carry out the most reliable diagnosis and document it thoroughly. If its purpose is to ensure the health of the child, i.e. when the baby is treated subjectively, no ethical doubts are raised. However, there is a risk that prenatal diagnosis will become a tool for eugenics. The reasons for conducting prenatal diagnosis are also important. First, the need to conduct genetic tests should be assessed. This applies particularly to invasive methods, which, as mentioned earlier, bring a threat to the child. The most crucial ethical issue concerns the decisions that parents take after the diagnosis has been made, which, if unfavorable, often results in the decision to perform abortion. This stands in a complete contradiction to the Christian vision of the inviolability of human life from conception to natural death.

Another ethical issue related to genetic testing concerns one of the contemporary bioethical currents of thought - utilitarianism ${ }^{13}$. The utilitarian approach has its source in consequentialist theories. From the consequentialist point of view, moral acts are judged on the basis of their outcomes. Therefore, it is not universal values and norms that determine moral judgment, but the balance of profits and losses of a given action. Utilitarianism evaluates the human person in a very specific way. Man is a representative of the Homo sapiens species, but he acquires human rights only under specific conditions. According to Peter Singer, a leading representative of bio-utilitarianism, by belonging to Homo sapiens, man is not automatically granted his moral status. Singer also distinguishes the mere membership of the human species from other typically human characteristics (e.g. self-awareness, self-control, the ability to establish relationships with

\footnotetext{
13 Cf. R. Zubrzycka, Człowiek głębiej upośledzony umysłowo jako wartość zagrożona, in: Osoba $z$ upośledzeniem umysłowym w realiach współczesnego świata, ed. M. Chodkowska, D. Osik-Chudowolska, Kraków 2011, p. 63.
} 
others or communication $)^{14}$. The fact that every member of the Homo sapiens species has human genes does not necessarily mean that they have human characteristics. According to Singer, for instance, patients in irreversible coma, embryos or fetuses, as well as infants belong to the human species as they have human genes, but do not possess human qualities since they are not conscious beings ${ }^{15}$. They are members of the species, but not people, and only people can have the right to life and protection of their integrity ${ }^{16}$. What does this mean for children with intellectual disabilities? Every unborn child, as an unaware being, does not yet have the right to exist, and therefore abortion should not be judged as morally negative. Representatives of utilitarianism go even further in their deliberations and state that the killing of a newborn should be acceptable from a moral point of view as infants are still unaware representatives of the Homo sapiens species and have no human characteristics. If a child, due to a profound mental disability, is not aware of themselves or their life, and does not enter into relationships - in other words - if a child does not meet the criteria and, thus, cannot be thought to possess human characteristics, he or she is not considered a person from the point of bio-utilitarianism and does not have a right to life as long as they remain in such a state. The concept of bio-utilitarianism, therefore, gives consent to the killing of people with a profound intellectual disability at any time in their lives. In the context of genetic testing, it opens the way to abortion of each child diagnosed with a disability regardless of the stage of pregnancy. While it may be assumed that the killing of newborns would meet with public opposition, abortions of children with a diagnosed disability at any stage of pregnancy could be accepted.

\footnotetext{
14 Cf. A. Lohner, Historyczne korzenie etycznych pogladów Petera Singera, in: Utylitaryzm w bioetyce. Jego założenia i skutki na przykładzie poglądów Petera Singera, ed. W. Bołoz, G. Hover, Warszawa 2002, p. 52.

15 Cf. ibid., p. 56.

16 Cf. E. Picker, Godność człowieka a życie ludzkie. Rozbrat dwóch fundamentalnych wartości jako wyraz narastającej relatywizacji człowieka, Warszawa 2007, p. 18-19.
} 
In this case, genetic diagnosis becomes a tool in the service of eugenics, which from a Christian point of view, is morally unacceptable. Singer says that "in the case of a particular constitution, marked by underdevelopment, disease or senile dementia, a person would not have the 'right to life' yet or no longer have this right"17. It follows from this assumption that infants with intellectual disabilities are less entitled to life than babies of normal intellectual development. The reason for the killing of an unborn child may be, for example, a Down syndrome; with regard to early euthanasia, Singer believes that it should be permitted up to a month after birth. While euthanasia of older children and adults with intellectual disabilities should be done with their consent ${ }^{18}$.

According to Singer, permanent disability is a negative experience not only for the person affected by a disability, but also for their loved ones, and even the whole of a healthy society in which a disabled person lives. For both a disabled person as well as his or her family and relatives it would be better, if their life with a disability did not exist. Singer says it is a good and rational reason to allow parents to kill their disabled children. From this view stems the idea of wrongful life i.e. "life unworthy of living" 19 , which evokes the idea of Nazi medicine (lebensunwertes Leben), justifying the murder of sick and disabled people.

\section{Conclusion}

Nowadays, there are a number of methods of diagnosing intellectual disability, one of which is genetic diagnosis (prenatal and postnatal). The discussion on genetic diagnosis includes the reflection on the moral aspect of conducting genetic testing. Prenatal diagnosis is justified if it aims to administer treatment to the baby or create special

17 Ibid.

18 Cf. A. Lohner, Historyczne korzenie etycznych poglądów Petera Singera, op. cit., p. 52 .

19 Cf. R. Zubrzycka, Człowiek głębiej upośledzony umysłowo jako wartość zagrożona, op. cit., pp. 66-67. 
conditions for the baby, and provide specialized equipment for the treatment of the child after birth. From a Christian point of view, it is morally unacceptable that genetic testing become a tool in the realization of the concept of wrongful life or the idea of bio-utilitarianism, both of which promote eugenics. The life and integrity of every human being should always and without exception be respected ${ }^{20}$.

\section{Summary}

The article presents a reflection on the genetic diagnosis of intellectual disability. Attention was drawn to the moral aspect of genetic testing and it was emphasized that genetic diagnosis must not become an instrument in the implementation of bio-utilitarianism or the concept of wrongful life, according to which, whether a person can be considered a human being, and thus have the right to life, depends on certain factors, and is not self-evident by the very fact of belonging to the human species.

\section{Streszczenie}

Artykuł zawiera refleksje dotyczące diagnostyki genetycznej zaburzeń intelektualnych. Autorka zwraca szczególną uwagę na aspekt moralny. Podkreśla, że diagnostyka genetyczna nie może być narzędziem bio-utylitaryzmu czy koncepcji wrogiej życiu zawierającej się w indywidualnej decyzji czy daną osobę można uznać za człowieka i stąd czy ma prawo do życia.

Keywords: intellectual disability, genetic diagnosis, genetic diseases, prenatal genetic test, postnatal genetic test, bioethical problem, utilitarianism, eugenic, abortion, euthanasia, concept of wrongful life

\section{Bibliography}

Błeszyński J. J., Niepełnosprawność intelektualna. Mowa - język - komunikacja. Czy iloraz inteligencji wyjaśnia wszystko?, Gdańsk 2013.

Harper P. S., What do we mean by genetic testing?, "Journal of Medical Genetics" 1997, No. 34, p. 749.

Jan Paweł II, Evangelium Vitae. Encyclical.

Kongregacja Nauki Wiary, Dignitas personae. Instrukcja dotycząca niektórych problemów bioetycznych, Watykan 2008.

${ }^{20}$ Cf. Jan Paweł II, Evangelium Vitae. Encyklika. 
Lohner A., Historyczne korzenie etycznych pogladów Petera Singera, in: Utylitaryzm $w$ bioetyce. Jego założenia i skutki na przykładzie pogladów Petera Singera, ed. W. Bołoz, G. Hover, Warszawa 2002.

Picker E., Godność człowieka a życie ludzkie. Rozbrat dwóch fundamentalnych wartości jako wyraz narastajacej relatywizacji człowieka, Warszawa 2007.

Surmiak W., Eugenika a testy genetyczne, "Osoby niepełnosprawne a życie rodzinne" 2011, No. 1/4.

Upośledzenie umysłowe - pedagogika, ed. K. Kirejczyk, Warszawa 1981.

Wyczesany J., Pedagogika upośledzonych umystowo. Wybrane zagadnienia, Kraków 1999.

Zubrzycka R., Człowiek głębiej upośledzony umysłowo jako wartość zagrożona, in: Osoba $z$ upośledzeniem umysłowym $w$ realiach współczesnego świata, ed. M. Chodkowska, D. Osik-Chudowolska, Kraków 2011.

Zofia Kępińska-Walczak - mgr teologii, doktorantka teologii pastoralnej na UKSW, absolwentka Instytutu Wiedzy o Kulturze (obecnie: Instytut Dialogu Kultury i Religii) na UKSW w Warszawie, wolontariuszka w Stowarzyszeniu Rodzin i Opiekunów Osób z Zespołem Downa „Bardziej Kochani”, zainteresowania naukowe: duszpasterstwo nadzwyczajne, personalizm chrześcijański, religijność ludowa. 